\begin{tabular}{|c|c|c|c|c|c|c|c|c|}
\hline \multicolumn{3}{|c|}{$\begin{array}{l}\text { 2. To: (Receiving Organization) } \\
\text { Distribution }\end{array}$} & \multicolumn{2}{|c|}{$\begin{array}{l}\text { 3. Irom: (Originating Organization) } \\
\text { CVD Project }\end{array}$} & \multicolumn{4}{|c|}{$\begin{array}{l}\text { 4. Related EDT No.: } \\
\text { N/A }\end{array}$} \\
\hline \multicolumn{3}{|c|}{$\begin{array}{l}\text { 5. Proj./Prog./Dept./Div.: } \\
\text { SNF Project/W-441 }\end{array}$} & \multicolumn{2}{|c|}{$\begin{array}{l}\text { 6. Design Authority/ Design Agent/Cog. Engr.: } \\
\text { S. A. Brisbin }\end{array}$} & \multicolumn{4}{|c|}{ 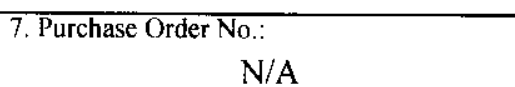 } \\
\hline \multicolumn{5}{|c|}{$\begin{array}{l}\text { 8. Originator Remarks: } \\
\text { The attached document is being submitted for approval and release. }\end{array}$} & \multicolumn{4}{|c|}{$\begin{array}{r}\text { 9. Equip./Component No.: } \\
\text { NA }\end{array}$} \\
\hline \multicolumn{5}{|c|}{ 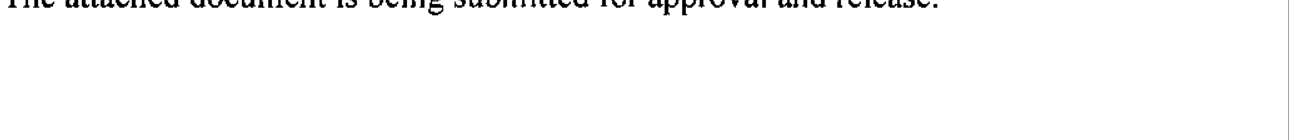 } & \multicolumn{4}{|c|}{$\begin{array}{l}\text { 10. System/BIdg./Facility: } \\
\qquad 142-\mathrm{K} / \mathrm{CVDF}\end{array}$} \\
\hline \multirow{3}{*}{\multicolumn{5}{|c|}{ 11A. Design Baseline Document? [] Yes [X] No }} & \multicolumn{4}{|c|}{$\begin{array}{l}\text { 12. Major Assm. Dwg. No.: } \\
\text { N/A }\end{array}$} \\
\hline & & & & & \multicolumn{4}{|c|}{$\begin{array}{c}\text { 13. Permit/Permit Application No.: } \\
\text { N/A }\end{array}$} \\
\hline & & & & & \multicolumn{4}{|c|}{ 14. Required Response Date: } \\
\hline 15. & & $\overline{\text { DATA }}$ & TRANSMIT & & $(\mathrm{F})$ & (G) & (H) & (I) \\
\hline $\begin{array}{l}\text { (A) } \\
\text { Item } \\
\text { No. }\end{array}$ & (B) Documentidrawing No. & $\begin{array}{l}\text { (C) } \\
\text { Sheet } \\
\text { No. }\end{array}$ & \begin{tabular}{l|l} 
(D) \\
Rvev. \\
No.
\end{tabular} & (E) Title or Description of Data Transmitted & $\begin{array}{c}\text { Approval } \\
\text { Desig- } \\
\text { nator }\end{array}$ & $\begin{array}{l}\text { Reason } \\
\text { for Trans- } \\
\text { mittal }\end{array}$ & $\begin{array}{l}\text { Origi- } \\
\text { nator } \\
\text { Dispo- } \\
\text { sition }\end{array}$ & $\begin{array}{l}\text { Receiv- } \\
\text { er } \\
\text { Dispo- } \\
\text { sition }\end{array}$ \\
\hline 1 & SNF-5484 & All & 0 & $\begin{array}{l}\text { Cold Vacuum Drying Facility } \\
\text { Acceptance for Beneficial Use }\end{array}$ & NA & 1,2 & 1 & \\
\hline & & & & & & & & \\
\hline
\end{tabular}

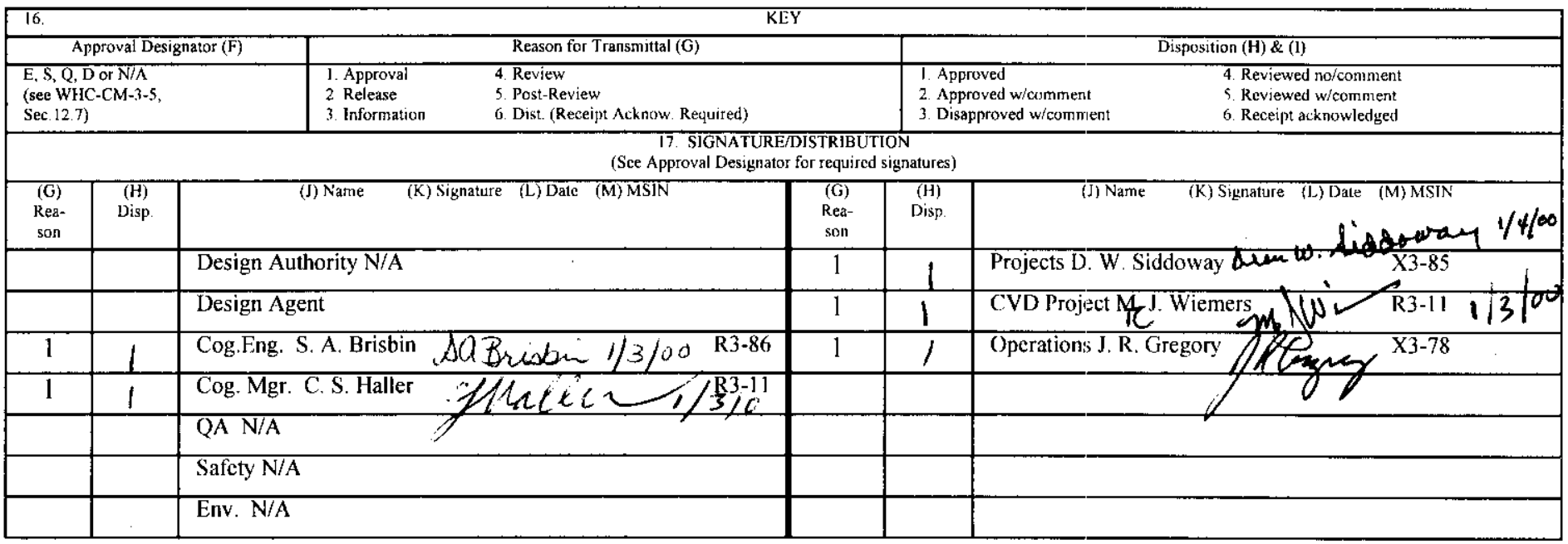
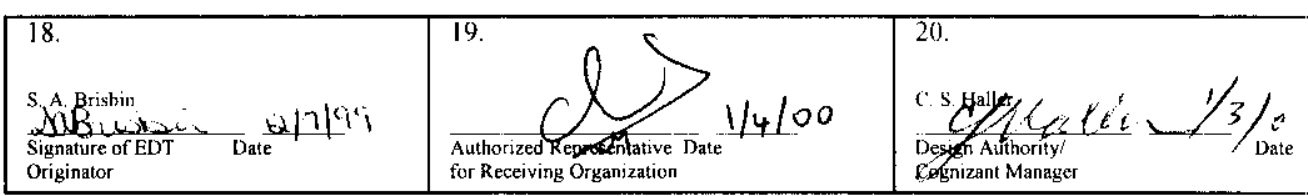
1. DOE APPROVAL (if required) Ctrl. No.
[] Approved
[] Approved w/comments
II Disapproved w/comments




\title{
Cold Vacuum Drying Facility Acceptance For Beneficial Use
}

\author{
S. A. Brisbin \\ Fluor Daniel Hanford, \\ Richland, WA 99352 \\ U.S. Department of Energy Contract DE-AC06-96RL13200 \\ EDT/ECN: 627124 \\ UC: 510 \\ Org Code: $2 \mathrm{~F} 000$ \\ CACN: 105539 \\ COA: A000 \\ B\&R Code: 39EW70400 Total Pages: 7 \\ Key Words: SNF, CVD, W-441, Turnover, Acceptance
}

Abstract: This document provides a checklist of the items required for turnover of the Cold Vacuum Drying Facility from the Construction Projects organization to the Operations organization. This document will be updated periodically to document completion of additional deliverables.

TRADEMARK DISCLAIMER. Reference herein to any specific commercial product, process, or service by trade name, trademark. manufacturer, or otherwise, does not necessarily constitute or imply its endorsement, recommendation, or favoring by the United States Government or any agency thereof or its contractors or subcontractors.

Printed in the United States of America. To obtain copies of this document, contact: Document Control Services, P.0. Box 950, Marilstop H6-08, Richlandd WA 99352, Phone (509) 372-2420; Fax (509) 376-4989.
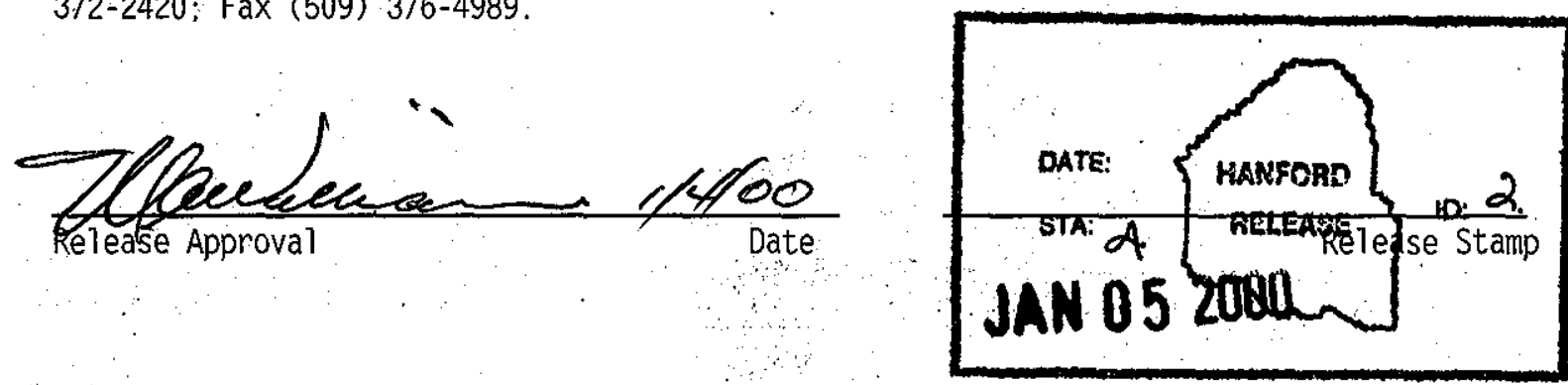

Approved for Public Release 
COLD VACUUM DRYING FACILITY (W-441)

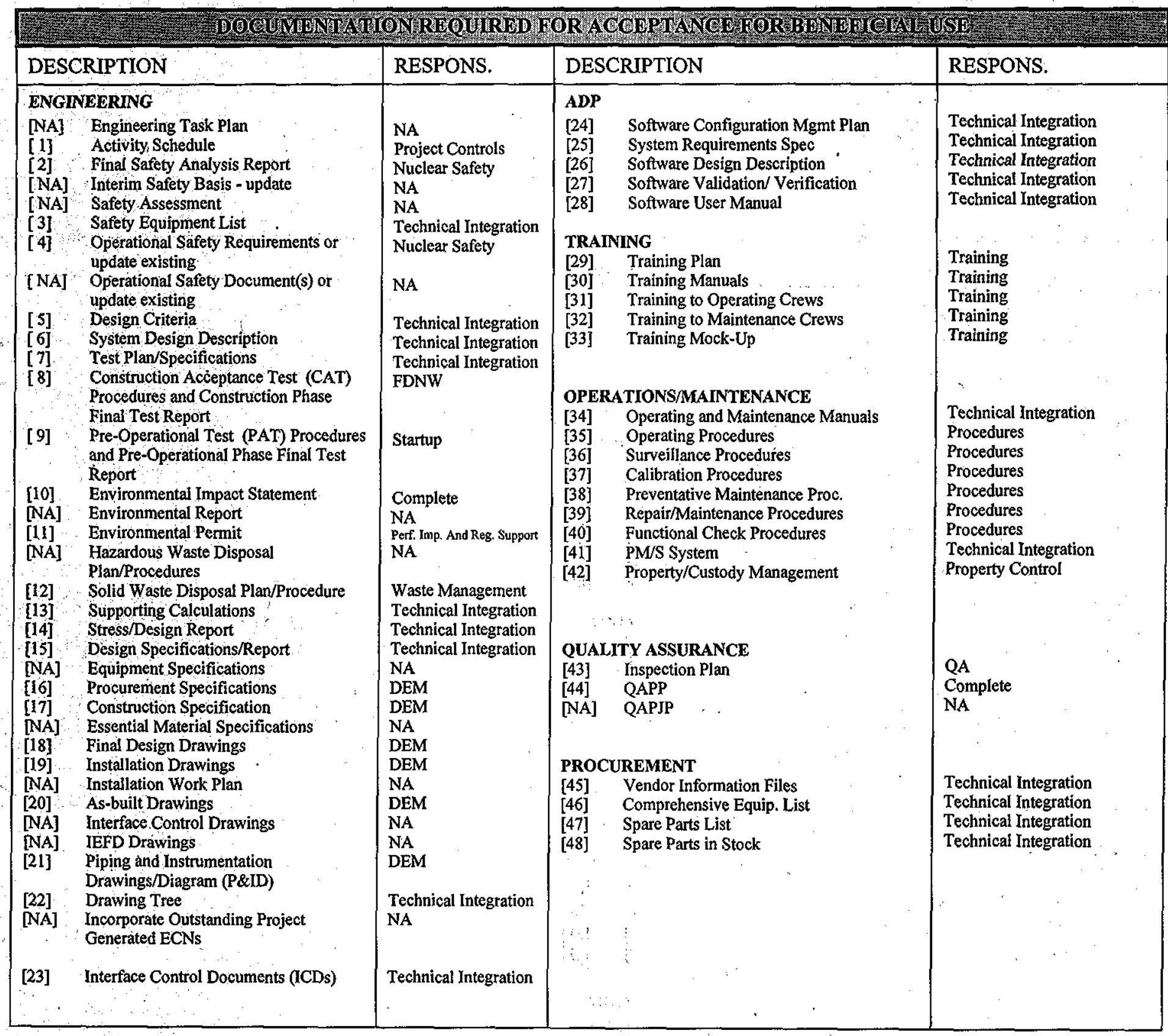

DEM - Design Engineering Manager

NA - Not Applicable to the CVDF 


\begin{tabular}{|c|c|}
\hline & 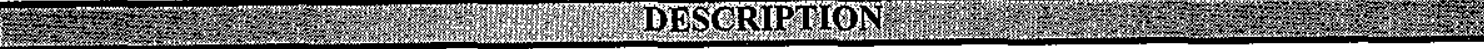 \\
\hline$\frac{1}{2 a}$ & \\
\hline $2 a$ & Final Safety Analysis Report, ref. HNF-3553, Appendix B \\
\hline $2 b$ & Complete SER Actions. \\
\hline 3 & HNF-SD-SNF-SEL-002, Safety Equipment List \\
\hline 4 & Operational Safety Requirements, ref. HNF-3673, Cold Vacuum Drying Facility Technical Safety Requirements \\
\hline $5 \mathbf{a}$ & $\begin{array}{l}\text { Design Criteria for the CVDF are provided in HNF-SD-SNF-DRD-002, Design Reguirements Document for the Cold Vacuum } \\
\text { Drying Facility. }\end{array}$ \\
\hline $5 \mathrm{~b}$ & Design Verification and Validation Plan for the Cold Vacuum Drying Facility, SNF-4396. \\
\hline 6 & $\begin{array}{l}\text { System Design Descriptions (SDDs). The SDD content as agreed upon } 2 / 99 . \text { The following SDDs will be provided in a format } \\
\text { following DOE-STD-3024-98 (dated October 1998): }\end{array}$ \\
\hline $6 a$ & SNF-3060, Radiation Monitoring (RM) and Room Air Quality (AQ) \\
\hline $6 \mathrm{~b}$ & SNF-3061, Civil/Structural Systems (CIV) \\
\hline $6 c$ & SNF-3062, Vacuum Purge System (VPS) \\
\hline $6 \mathrm{~d}$ & SNF-3063, Residual Gas Monitoring System (RGM) \\
\hline $6 \mathrm{e}$ & SNF-3064, Helium MSLD and Auxiliary Vacuum (MSLD) \\
\hline $6 f$ & SNF-3065, Communication Systems (COMM) \\
\hline $6 \mathrm{~g}$ & SNF-3066, Compressed Air System (CA/CI) \\
\hline $6 \mathrm{~h}$ & SNF-3067, General Service Helium System $(\mathrm{He})$ \\
\hline 61 & SNF-3068, Safety Class Helium (SCHe) \\
\hline $6 j$ & SNF-3072, Cranes and Hoists (HOI) \\
\hline $6 \mathrm{k}$ & SNF-3073, Effluent Drains System (EFS) \\
\hline 61 & SNF-3074, Condensate Collection System (CCS) \\
\hline $6 \mathrm{~m}$ & SNF-3075, Electrical Systems (ES) \\
\hline $6 n$ & SNF-3076, Specialty Equipment and Tools \\
\hline 60 & SNF-3077, Service Water System (SWS) and Fire Protection System (FP) \\
\hline $6 \mathrm{p}$ & SNF-3078, De-ionized Water System (DI) \\
\hline $6 q$ & SNF-3079, Potable Water System (PW) \\
\hline $6 r$ & SNF-3080, Sewage Collection System (SANS) \\
\hline$\because 6 \mathrm{~s}$ & SNF-3081, HVAC Systems (HVAC) \\
\hline $6 \mathrm{t}$ & SNF-3082, Process Water Conditioning System (PWC) \\
\hline $6 u$ & SNF-3085, Tempered Water/Tempered Water Cooling (TW/TWC) \\
\hline $6 \mathrm{v}$ & SNF-3086, Chilled Water System (CW) \\
\hline $6 \mathrm{w}$ & SNF-3087, Vacuum and Purge System Chilled Water (VPSCHW) \\
\hline $6 x$ & SNF-3088, Stack Monitoring System (SM) \\
\hline $6 y$ & SNF-3089, Security System (SEC). . PHMC Security will prepare and maintain a more detailed SDD than SNF-3089. \\
\hline $6 z$ & SNF-3090, Monitoring and Control System (MCS) \\
\hline 6aa & SNF-3091, Safety Class Instrumentation and Control (SCIC) \\
\hline $6 \mathrm{ab}$ & SNF-3083, Cask/MCO Handling \\
\hline 7 & $\begin{array}{l}\text { Test Plans/Specifications and Reports. Test summary reports will be prepared to verify compliance with the test specifications } \\
\text { approved by the JTG. }\end{array}$ \\
\hline $7 \mathbf{a}$ & $\begin{array}{l}\text { WHC-SD-SNF-TP-018, SNF Proof of Performance Test Specification and Test Plan/HNF-SD-SNF-TRP-021, Hanford Spent } \\
\text { Nuclear Fuel Cold Vacuum Drying Proof of Concept Test Report }\end{array}$ \\
\hline $7 \mathrm{~b}$ & $\begin{array}{l}\text { HNF-SD-SNF-TP-036, SNF Cold Vacuum Drying Test Specification and Test Plan/HNF-3342, Hanford Spent Nuclear Fuel Cold } \\
\text { Vacuum Drying First Article Initial Test Finding Report }\end{array}$ \\
\hline $7 \mathrm{c}$ & SNF-441-TS-005-1, Health Protection (HP) \\
\hline$\overline{7 d}$ & SNF-441-TS-005-2, 02 Monitoring (RM) \\
\hline $7 \mathrm{e}$ & SNF-441-TS-006, Telescoping Doors/Roll-up (Facility Buildings) \\
\hline $7 f$ & SNF-441-TS-011, Communication/HLAN \\
\hline $7 \mathrm{~g}$ & SNF-44I-TS-012, Compressed Air/Instrument Air (CA/IA) \\
\hline $7 \mathrm{~h}$ & SNF-441-TS-018, Drainage Systems \\
\hline $7 \mathrm{I}$ & SNF-441-TS-020-1, Electrical Power Distribution \& Misc. \\
\hline $7 \mathbf{j}$ & SNF-441-TS-020-4, UPS \\
\hline $7 \mathrm{k}$ & SNF-44l-TS-024, Fire Protection/Detection \\
\hline
\end{tabular}




\begin{tabular}{|c|c|}
\hline 7 & 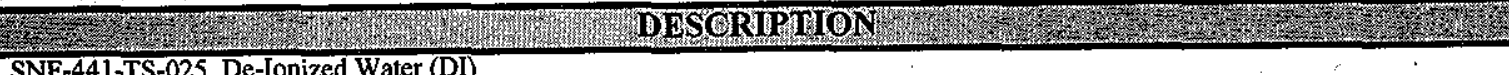 \\
\hline 71 & SNF-441-TS-025, De-lonized Water (DI) \\
\hline $7 \mathrm{~m}$ & SNF-441-TS-026, Potable Water \\
\hline $7 \mathrm{n}$ & SNF-441-TS-027, Sewage Water System (SANS) \\
\hline 70 & SNF-441-TS-030-1, HVAC-A Admin Bldg. \\
\hline $7 \mathrm{p}$ & SNF-441-TS-030-2, HVAC-B Process Bay Recirc Supply and Exhaust \\
\hline $7 \mathrm{q}$ & SNF-441-TS-030-3A,HVAC-C Process Bay Local Exhaust \\
\hline $7 \mathbf{r}$ & SNF-441-TS-030-5, Reference Air System \\
\hline $7 \mathrm{~s}$ & SNF-441-TS-047-3, Chilled Water \\
\hline$\overline{7 t}$ & SNF-441-TS-047-4, Vacuum Purge System Chilled Water (VPSCHW) \\
\hline $7 \mathrm{u}$ & SNF-441-TS-054/55, Security (SEC) \\
\hline $7 v$ & SNF-441-TS-007-1, Vacuum Purge System, Bay 2 (no longer required due to 3 bay strategy) \\
\hline $7 \mathrm{w}$ & SNF-441-TS-007-2, Vacuum Purge System, Bay 3 \\
\hline$\overline{7 x}$ & SNF-441-TS-007-3, Vacuum Purge System, Bay 4 \\
\hline $7 y$ & SNF-441-TS-007-4, Vacuum Purge System, Bay 5 \\
\hline $7 z$ & SNF-441-TS-007-5, Simulated MCO Processing \\
\hline $7 \mathrm{aa}$ & SNF-441-TS-013-1, Helium \\
\hline $7 \mathrm{ab}$ & SNF-441-TS-013-2, Safety Class Helium \\
\hline $7 \mathrm{ac}$ & SNF-441-TS-014, Cranes/Hoists \\
\hline $7 \mathrm{ad}$ & $\begin{array}{l}\text { SNF-441-TS-020-5, Heat Trace. No longer required. Heat trace added with DCN } 196 \text { was deleted by DCN } 285 \text {. VPS heat trace } \\
\text { should be tested with that system. }\end{array}$ \\
\hline $7 \mathrm{ae}$ & SNF-441-TS-030-3B, HVAC-C Process Bay Local Exhaust Process Hood \\
\hline 7af & SNF-441-TS-046, Process Water Conditioning, Contaminate Water Sampling and Analysis and Rad Effluent Handling and Disposal \\
\hline $7 \mathrm{ag}$ & SNF-441-TS-047-1, Tempered Water (Annulus) (TW) \\
\hline $7 \mathrm{ah}$ & SNF-441-TS-047-2, Tempered Water Cooling (TWC) \\
\hline $7 \mathrm{ai}$ & SNF-441-TS-050-1, Stack Monitoring (SM) Phase 1 \\
\hline $7 \mathrm{aj}$ & SNF-441-TS-093-1, Monitoring and Control System (MCS) \\
\hline $7 a ̈ k$ & SNF-441-TS-093-2, Safety Class Instrumentation (SCI\&C) \\
\hline 8 & $\begin{array}{l}\text { CAT Procedure(s)/Report. CATs will be completed as required in the approved test specifications. Test results will be included in } \\
\text { test summary reports used to verify conformance with test specifications. }\end{array}$ \\
\hline 9 & PAT Procedure(s)/Report \\
\hline $9 a$ & SNF-441-PAT-005-1, Health Protection (HP). Not required. HP equipment will be tested under the control of construction forces. \\
\hline $9 \mathrm{~b}$ & $\begin{array}{l}\text { SNF-441-PAT-005-2, } 02 \text { Monitoring (AQ). Not required. } 02 \text { monitoring will be tested will be tested under the control of } \\
\text { construction forces. }\end{array}$ \\
\hline $9 \mathrm{c}$ & $\begin{array}{l}\text { SNF-441-PAT-006, Telescoping Doors/Roll-up (Facility Buildings). Not required. The telescoping/roll-up doors will be tested by } \\
\text { construction forces. }\end{array}$ \\
\hline $9 \mathrm{~d}$ & SNF-441-PAT-011, Communication/HLAN. Not required. The communication/HLAN system will be tested by US West. \\
\hline $9 \mathrm{e}$ & SNF-441-PAT-012, Compressed Air/Instrument Air (CA/IA) \\
\hline $9 f$ & SNF-441-PAT-018, Drainage Systems. Drainage systems will be tested as part of the Fire Protection system ATP. \\
\hline $9 \mathrm{~g}$ & $\begin{array}{l}\text { SNF-44l-PAT-020-1, Electrical Power Distribution \& Misc: Not required. This system will be tested with other systems. A specific } \\
\text { PAT is not required. }\end{array}$ \\
\hline $9 \mathrm{~h}$ & SNF-441-PAT-020-4, UPS. Not required. The UPS will be tested by construction forces/vendor. \\
\hline $9 \mathrm{i}$ & SNF-441-PAT -024, Fire Protection / Detection. Not required. The fire alarm system will be covered by an ATP. \\
\hline $9 \mathrm{j}$ & $\begin{array}{l}\text { SNF-441-PAT -025, De-Ionized Water (DI). Not required. The DI system is a vendor supplied unit that will be tested under the } \\
\text { control of construction forces. }\end{array}$ \\
\hline $9 \mathrm{k}$ & SNF-441-PAT -026, Potable Water. Not required. The potable water system will be tested under the control of construction forces. \\
\hline 91 & $\begin{array}{l}\text { SNF-441-PAT }-027 \text {, Sewage Water System (SANS). Not required. The Sewage system will be tested under the control of } \\
\text { construction forces. }\end{array}$ \\
\hline $9 \mathrm{~m}$ & $\begin{array}{l}\text { SNF-441-PAT }-030-1, \text { HVAC-A Admin Bldg. Not required. The Admin HVAC system will be tested under the control of } \\
\text { construction forces. }\end{array}$ \\
\hline 9 n & SNF-441-PAT -030-2A, HVAC supply/exhaust/recirc \\
\hline 90 & SNF-44I-PAT -030-2B, HVAC Integrated \\
\hline $9 \mathrm{p}$ & SNF-441-PAT -030-5, Reference Air System. Not required. The RA system will be tested under SNF-441-PAT -030-2B. \\
\hline $9 q$ & SNF-441-PAT $047-3$, Chilled Water \\
\hline $9 \mathrm{r}$ & SNF-441-PAT -047-4, Vacuum Purge System Chilled Water (VPSCHW) \\
\hline $9 \mathrm{~s}$ & SNF-441-PAT -054/55, Security (SEC). Not required. The security system will be tested using an ATP. \\
\hline $9 \mathrm{t}$ & SNF-441-PAT -007-1, Vacuum Purge System, Bay 2. No PAT required. \\
\hline
\end{tabular}




\begin{tabular}{|c|c|}
\hline 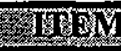 & 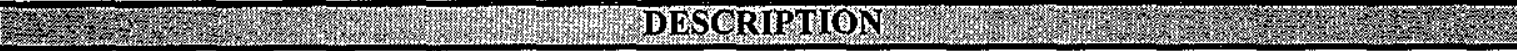 \\
\hline 9u & SNF-441-PAT -007-2, Vacuum Purge System, Bay 3. No PAT required. \\
\hline $9 \mathrm{v}$ & SNF-441-PAT -007-3, Vacuum Purge System, Bay 4. No PAT required. \\
\hline $9 \mathrm{w}$ & SNF-441-PAT -007-4, Vacuum Purge System, Bay 5. No PAT required. \\
\hline $9 x$ & SNF-441-PAT -007-7, Simulated MCO Processing Bay 4 \\
\hline $9 y$ & SNF-441-PAT -007-8, Simulated MCO Processing Bay 5 \\
\hline $9 z$ & SNF-441-PAT -013-1, Helium. Not required. The Helium system will be tested with the Safety Class Helium system. \\
\hline 9 aa & SNF-441-PAT -013-2, Safety Class Helium Bay 4 \\
\hline $9 \mathrm{ab}$ & SNF-441-PAT -013-3, Safety Class Helium Bay 5 \\
\hline $9 \mathrm{ac}$ & SNF-441-PAT -014 , Cranes/Hoists. Not required. The cranes system will be tested under the control of construction forces. \\
\hline 9ad & SNF-441-PAT -020-5, Heat Trace \\
\hline $9 \mathrm{ae}$ & SNF-441-PAT -030-3B-3, HVAC-C Process Bay Local Exhaust Process Hood Bay 4 \\
\hline $9 \mathrm{af}$ & SNF-441-PAT -030-3B-4, HVAC-C Process Bay Local Exhaust Process Hood Bay 5 \\
\hline 9ag & $\begin{array}{l}\text { SNF-441-PAT -046, Process Water Conditioning, Contaminate Water Sampling and Analysis and Rad Effluent Handling and } \\
\text { Disposal. Not required. Covered by SNF-441-PAT -007-7 and SNF-441-PAT -007-8 }\end{array}$ \\
\hline $9 \mathrm{ah}$ & SNF-441-PAT -047-1, Tempered Water (Annulus) (TW). No PAT required. \\
\hline 9 ai & SNF-441-PAT -047-2, Tempered Water Cooling (TWC) \\
\hline 9 aj & SNF-44I-PAT -050-1, Stack Monitoring (SM) Phase I \\
\hline 9ak & SNF-441-PAT $\backsim 050-2$, Stack Monitoring (SM) Phase 2 \\
\hline 9al & SNF-441-PAT $-093-1$, Monitoring and Control System (MCS) \\
\hline 9am & SNF-441-PAT -093-2C, Safety Class Instrumentation (SCI\&C) Bay 4 \\
\hline 9 an & SNF-441-PAT -093-2D, Safety Class Instrumentation (SCI\&C) Bay 5 \\
\hline 10 & $\begin{array}{l}\text { Environmental Impact Statement for the SNF Project was issued. Ref. DOEE/EIS-0245F, Management of Spent Nuclear Fuel from } K \\
\text { Basins at the Hanford Site, Richland, Washington.. }\end{array}$ \\
\hline 11 & Environmental Permit, ref. DOE/RL.-96-110, Rev. 1. Air permit revision approved May 1999. \\
\hline 12 & Solid Waste Disposal Plan/Procedure. Annual update of waste forecasts will be performed. \\
\hline 13 & $\begin{array}{l}\text { Supporting Calculations are identified in SNF-3001, Cold Vacuum Drying Facility Supporting Data and Calculation Database. This } \\
\text { document will be reviewed against the latest design to ensure required calculations are provided. The document will be revised as } \\
\text { necessary until the design is complete. A package of calculations referenced in SNF-3001 needs to be built. SNF-3001 identifies } \\
\text { calculations, including those prepared specifically for the FSAR }\end{array}$ \\
\hline 14 & Stress/Design Report. This information is provided in SNF-3001. \\
\hline $15 \mathrm{a}$ & Design parameters are provided in the DRD (see item 5). A comprehensive design report was prepared and reviewed in April 1999. \\
\hline $15 \mathrm{~b}$ & Close open items from the comprehensive design review. \\
\hline 16 & $\begin{array}{l}\text { Procurement Specifications - There are } 6 \text { procurement specifications associated with the CVDF Project, as identified in items } 16 \mathrm{a} \\
\text { through } 16 \mathrm{f} \text { below. }\end{array}$ \\
\hline $16 a$ & $\begin{array}{l}\text { SNF-5303, Procurement Specification for Fabrication, Acceptance Testing, and Shipment of the Cold Vacuum Drying Facility } \\
\text { Process Equipment Skid. } \\
\text { NOTE: This document is also referred to as CVDF specification number W-441-P1. } \\
\text { Procurement Specification W-441-P1 (Revision 3), released into Hanford document control system as supporting document } \\
\text { number SNF-5301, Revision } 0 \text {. Any changes will be controlled using the ECN process. The specification will be "as-built" prior } \\
\text { to project completion to reflect final equipment configuration and incorporation of outstanding ECNs }\end{array}$ \\
\hline $16 \mathrm{~b}$ & $\begin{array}{l}\text { SNF-5302, Procurement Specification for Fabrication, Acceptance Testing, and Shipment of the Cold Vacuum Drying Facility } \\
\text { Process Water Conditioning Skid. } \\
\text { NOTE: This document is also referred to as CVDF specification number W-441-P2. } \\
\text { Procurement Specification W-441-P2 (Revision 3), released into Hanford document control system as supporting document } \\
\text { number SNF-5302, Revision } 0 \text {. Any changes will be controlled using the ECN process. The specification will be "as-built" prior } \\
\text { to project completion to reflect final equipment configuration and incorporation of outstanding ECNs. }\end{array}$ \\
\hline $16 \mathrm{c}$ & $\begin{array}{l}\text { SNF-5457, Procurement Specification for the Monitoring and Control System of the Cold Vacuum Drying Facility. } \\
\text { NOTE: This document is also referred to as CVDF specification number W-441-P3. } \\
\text { Procurement Specification W-441-P3 will be released into Hanford document control system as supporting document number } \\
\text { SNF-5457, Revision 0. Any subsequent changes will be controlled using the ECN process. The specification will be "as-built" } \\
\text { prior to project completion to reflect final equipment configuration and incorporation of outstanding ECNs }\end{array}$ \\
\hline
\end{tabular}




\begin{tabular}{|c|c|}
\hline & 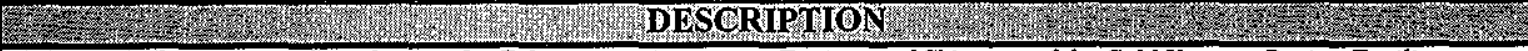 \\
\hline $16 \mathrm{~d}$ & $\begin{array}{l}\text { SNF-5303, Procurement Specification for Fabrication, Acceptance Testing, and Shipment of the Cold Vacuum Drying Facility } \\
\text { Process Hood and Piping Assembly. } \\
\text { NOTE: This document is also referred to as CVDF specification number W-441-P4. } \\
\text { Procurement Specification W-441-P4 (Revision 3), released into Hanford document control system as supporting document } \\
\text { number SNF-5303, Revision } 0 \text {. Any changes will be controlled using the ECN process. The specification will be "as-built" prior } \\
\text { to project completion to reflect final equipment configuration and incorporation of outstanding ECNs }\end{array}$ \\
\hline $16 e$ & $\begin{array}{l}\text { SNF-5304, Procurement Specification for Fabrication, Acceptance Testing, and Shipment of the Cold Vacuum Drying Facility } \\
\text { Process Safety Class Helium System Equipment. } \\
\text { NOTE: This document is also referred to as CVDF specification number W-441-P5. } \\
\text { Procurement Specification W-441-P5 (Revision 3), released into Hanford document control system as supporting document } \\
\text { number SNF-5304, Revision 0. Any changes will be controlled using the ECN process. The specification will be "as-built" } \\
\text { prior to project completion to reflect final equipment configuration and incorporation of outstanding ECNs }\end{array}$ \\
\hline $16 f$ & $\begin{array}{l}\text { HNF-3229, Cold Vactum Drying Safety Class Instrumentation and Control System Performance Specification. } \\
\text { NOTE: This document replaces the cancelled CVDF specification W-441-P6. } \\
\text { HNF-3229 has been officially released into the Hanford document control system, and is currently at Revision 2a. Any changes } \\
\text { to this specification will continue to be controlled using the ECN process. The specification will be "as-built" prior to project } \\
\text { completion to reflect final system configuration and incorporation of outstanding ECNs. }\end{array}$ \\
\hline 17 & $\begin{array}{l}\text { W-441-C1, Construction Specification for Cold Vacuum Drying Facility. } \\
\text { Changes to the approved CVDF construction specification are controlled using the Document Change Notice (DCN) process. } \\
\text { Specification W-441-C1 will be "as-built" prior to project completion to reflect final facility configuration and incorporation of } \\
\text { outstanding ECNs. The final as-built specification will be released into the Hanford document control system as SNF-5458 }\end{array}$ \\
\hline 18 & Final Design Drawings - see H-1-83946 (item 22 below) \\
\hline 19 & Installation Drawings - see H-1-83946 (item 22 below). \\
\hline 20 & $\begin{array}{l}\text { As-Built Drawings. Drawings identified in the CVDF Drawing Tree, with the exception of vendor drawings, will be "as-built" and } \\
\text { released into the Hanford document control system in accordance with SNF-5182, Cold Vacuum Drying Facility As-Builting Plan. } \\
\text { Labeling will be included in the as-built verification process. The final as-builts will include incorporation of outstanding } \\
\text { DCNs/ECNs, NCRs, contractor red-lined drawing information, and field as-built verification data. As-built drawings will be } \\
\text { prepared and released incrementally as work on the applicable structure, system, or component (SSC) is completed. As-built } \\
\text { drawings will be completed prior to CVDF project completion. }\end{array}$ \\
\hline 21 & $\begin{array}{l}\text { Piping and Instrumentation Drawings/Diagram (P\&ID) -- see H-1-83946 (item } 22 \text { below). P\&IDs associated with the CVDF facility } \\
\text { and process equipment are included in the CVDF Drawing Tree. Any changes to these approved drawings are controlled using the } \\
\text { DCN/ECN processes, as applicable. P\&IDs will be "as-built" as discussed in item } 20 \text { above, prior to project completion. }\end{array}$ \\
\hline 22 & $\begin{array}{l}\text { H-1-83946, Cold Vacuum Drying Facility Drawing Tree. Drawing H-1-83946 (includes multiple sheets) lists of the various facility } \\
\text { and process equipment drawings used for fabrication and construction (not including vendor drawings). The drawing tree was } \\
\text { originally released into the Hanford document control system as Revision 0. Changes to the drawing tree are controlled using the } \\
\text { ECN process. The Drawing Tree will be updated as required during the life of the CVDF Project to maintain a current listing of the } \\
\text { drawings, and it will be "as-built" prior to project completion to incorporate outstanding ECNs. }\end{array}$ \\
\hline 23 & $\begin{array}{l}\text { Interface Control Documents currently approved: } \\
\text { a. MCO Table } \\
\text { b. IC-001, Vacuum Dried K Basin Fuel in MCO/Cask } \\
\text { c. IC-012, Bulk Water from CVD to Retum to K Basin Integrated Water Treatment System } \\
\text { d. IC-043, MCO/Cask Loaded with Wet KE'Basin Fuel } \\
\text { e. IC-044, MCO/Cask Loaded with Wet KW Basin Fuel } \\
\text { f. IC-058, Treated K Basin Vacuum Dry Offgas Exhaust - Permitting for CVD Offgas Exhaust } \\
\text { g. IC-061, K Basin Vacuum Dry Offgas Filter Waste } \\
\text { h. IC-062, Cask Decon Waste After Vacuum Drying } \\
\text { i. IC-063, Vacuum Drying System Water Supply } \\
\text { j. IC-108, Vacuum Pump Oil and Oil Filter Waste to K.Basin Solid Waste Handling } \\
\text { k. IC-110, Electrical Power to Support the CVD Module } \\
\text { l. IC-111, Establish the CVD Module Support Requirements } \\
\text { m. IC-112, Telephone.Support for the CVD Module } \\
\text { n. IC-113, HLAN Connections for the CVD Module } \\
\text { o. IC-114, Fire Department Requirements for the CVD Module } \\
\text { p. IC-153, CVD Accountability } \\
\text { q. IC-162, Potable Water Supplied to the CVD Module } \\
\text { r. IC-163, Sanitary Services Supplied to the CVD Module } \\
\text { s. IC-164, Laundry Services Supplied to the CVD Module } \\
\text { t. IC-187, Cask Annulus Gas Sample to 222S Lab } \\
\text { u. IC-207, Use of CVDF for Sludge Transport Staging }\end{array}$ \\
\hline 24 & Software Configuration Management Plan \\
\hline $24 a$ & $\mathrm{MCS}$ \\
\hline
\end{tabular}




\begin{tabular}{|c|c|}
\hline 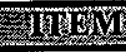 & W \\
\hline $24 \mathrm{~b}$ & SCIC \\
\hline $24 c$ & ATC \\
\hline 25 & System Requirements Specification \\
\hline $25 \mathrm{a}$ & MCS. Currently issued as a CH2M Hill document. Will be updated and issued as a SNF document. \\
\hline $25 b$ & SCIC. Two separate documents prepared by Framatome. These documents will be issued as SNF documents. \\
\hline $25 \mathrm{c}$ & ATC \\
\hline 26 & Software Design Description \\
\hline $26 a$ & MCS. Document will be released as an SNF document following PAT. \\
\hline$\ldots 26 \mathrm{~b}$ & SCIC. Two separate descriptions will be prepared by Framatome. These will be issued as SNF documents following PAT testing. \\
\hline $26 \mathrm{c}$ & ATC. This will be included in the user manual. \\
\hline 27 & Software Verification and Validation \\
\hline $27 \mathrm{a}$. & MCS. V\&V will consist of testing during the PAT. Test results will be documented in a test summary report \\
\hline $27 \mathrm{~b}$ & $\begin{array}{l}\text { SCIC. Framatome will perform formal V\&V. Results will be documented in a Framatome report and the Framtome final design } \\
\text { report. }\end{array}$ \\
\hline $27 \mathrm{c}$ & ATC. Total Energy will perform software V\&V. \\
\hline 28 & Software User Manual \\
\hline $28 \mathrm{a}$ & MCS. This document is being prepared by $\mathrm{CH} 2 \mathrm{M}$ Hill. The manual will be finalized and issued after the PAT. \\
\hline $28 b$ & SCIC. Not applicable. Code is embedded in chips. Pertinent information will be included in the software design description. \\
\hline $28 \mathrm{c}$ & ATC. Total Energy will provide a software user manual following testing. \\
\hline 29 & Training Plan \\
\hline 30 & Training Manuals \\
\hline 31 & Training of Operating Crews \\
\hline 32 & Training to Maintenance Crews \\
\hline 33 & Training Mock-up \\
\hline $34 \mathrm{a}$ & Operating Manual - HNF-2356, Spent Nuclear Fuel Project Cold Vacuum Drying Facility Operations Manual \\
\hline $34 \mathrm{~b}$ & SNF-5390, CVD Off-Normal Event Description and Alarm Response Manual \\
\hline 35 & Operating Procedures \\
\hline 36 & Surveillance Procedures \\
\hline 37 & Calibration Procedures \\
\hline 38 & Preventive Maintenance Procedures \\
\hline 39 & Repair/Maintenance Procedures \\
\hline 40 & Functional Check Procedures \\
\hline 41 & PM/S System ref. Administrative Procedure MN-7-001-02 \\
\hline $41 \mathrm{a}$ & Component/Equipment Data Files \\
\hline $41 \mathrm{~b}$ & Maintenance Implementation PIan, ref. SNF-MIP-001 \\
\hline 42. & Property/Custody Management \\
\hline 43 & $\begin{array}{l}\text { Inspection Plans. AI inspection plan/report will be provided when complete. AI will maintain the official open items list for the } \\
\text { project. }\end{array}$ \\
\hline 44 & QAPP ref. SNF Project QAPP. \\
\hline 45 & $\begin{array}{l}\text { Vendor Information Files will set up to maintain information supplied by the various equipment vendors. As a minimum, the VI } \\
\text { files will consist of equipment manufacturer's maintenance and operation manuals. VI files will be developed in accordance with AP } \\
\text { EN-6-026. }\end{array}$ \\
\hline 46 & $\begin{array}{l}\text { The Master Equipment List will provide a comprehensive list of of the equipment that is included in the CVDF. Ref. SNF-4148, } \\
\text { Master Equipment List }\end{array}$ \\
\hline 47 & $\begin{array}{l}\text { Spare Parts List will identify the recommended spare parts. The list will provide a description of the components recommended for } \\
\text { spares, the number of each component recommended, and potential suppliers. }\end{array}$ \\
\hline 48 & $\begin{array}{l}\text { A listing of spare parts in stock will be provided including the storage location at the time of turnover. A listing of project provided } \\
\text { spares will be prepared. The listing will be verified and accepted by QA. }\end{array}$ \\
\hline
\end{tabular}




\section{DISTRIBUTION SHEET}

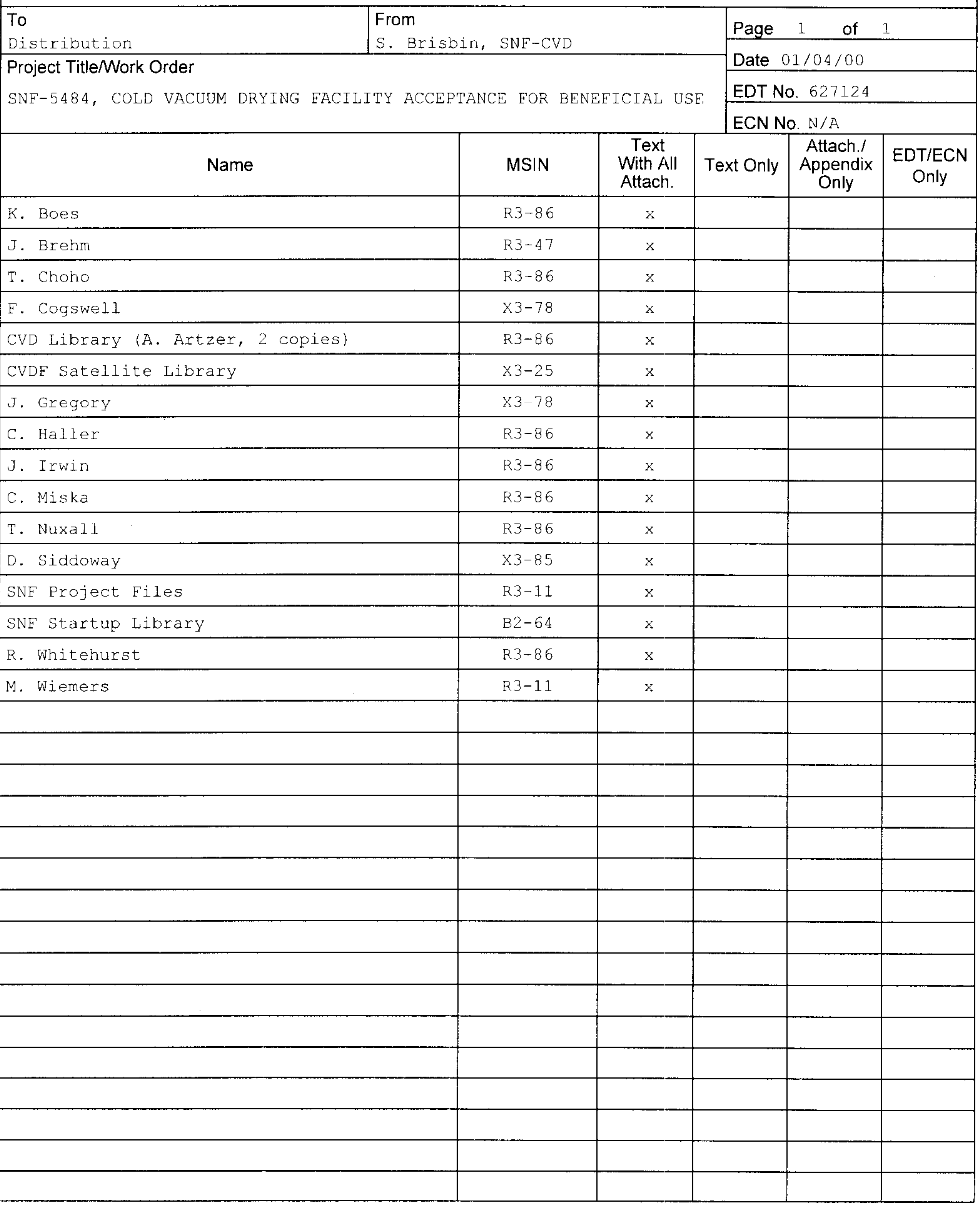

